\title{
Redescription of Monticellia magna (Rego, dos Santos \& Silva, 1974) (Eucestoda: Monticelliidae) parasite of Pimelodus spp. (Pisces: Siluriformes) from Argentina, and morphological study of microtriches
}

\section{Alicia A. GIL de PERTIERRA}

Laboratorio de Helmintología. Dpto. Biodiversidad y Biología Experimental. Facultad de Ciencias Exactas y Naturales. Universidad de Buenos Aires. Ciudad Universitaria, Pab. II, $4^{\circ}$ Piso. CP: C1428EHA-Buenos Aires, Argentina.

E-mail: helminto@bg.fcen.uba.ar

Redescription of Monticellia magna (Rego, dos Santos \& Silva, 1974) (Eucestoda: Monticelliidae) parasite of Pimelodus spp. (Pisces: Siluriformes) from Argentina, and morphological study of microtriches. Monticellia magna (Rego, dos Santos \& Silva, 1974) is redescribed and the microtriches and their distribution are studied for the first time. This species is characterised by the following combination of characters: (1) vagina anterior to cirrus pouch; (2) muscular asymmetrical sphincter present; (3) testes in one layer and in two fields connected anteriorly and posteriorly; (4) vitelline follicles distributed cortical, paramuscular and a few follicles medullary; (5) internal longitudinal musculature strongly developed; and (6) scolex with filiform microtriches in apical region, filiform and spiniform microtriches in central cavity, marginal ring and nonadherent surface of suckers, and spiniform microtriches in neck and immature proglottides. The species parasitised fishes of Pimelodus spp. Strict specificity of South American proteocephalids for their hosts is placed into consideration since recently new host records have been reported, especially for hosts commercially exploited.

Key-words: microtriches - Proteocephalidea - Monticellia magna Pimelodidae - host specificity - Argentina.

\section{INTRODUCTION}

Monticellia magna (Rego, dos Santos \& Silva, 1974) was originally described from Pimelodus clarias (Bloch, 1782) (junior synonym) (= P. blochii Valenciennes, 1840, original combination) as Nomimoscolex magna. However, de Chambrier \& Vaucher (1997) studied the type material and found it composed by specimens that belong to two different genera, Proteocephalus and Monticellia; and transferred N. magna to Monticellia. 
Latter, Rego \& Pavanelli (1992) described Monticellia loyolai from Pimelodus maculatus Lacépède, 1803. De Chambrier \& Vaucher (1999) synonymized this species with $M$. magna based on the study of the type material and new material collected in Paraguay. Eventhough, these authors exposed remarkable and distinctive characters for M. magna, and did not present drawings of this species.

During a survey of proteocephalidean cestodes from freshwater teleost fishes in Argentina, specimens of M. magna were collected from Pimelodus albicans (Valenciennes, 1840), $P$. argenteus Perugia, 1891, and P. maculatus. M. magna is described in detail for the first time in this paper, based on type and the new material. The surface of the tegument of the scolex and portions of the strobila were studied using scanning electron microscopy (SEM).

\section{MATERIAL AND METHODS}

Eighty specimens of $P$. albicans, 6 of $P$. argenteus and 212 of $P$. maculatus from Colastiné, La Plata, and Paraná rivers were examined for helminths. Worms found in the intestine were isolated and fixed in hot $4 \% \mathrm{v} / \mathrm{v}$ formaldehyde solution and stored in $75 \% \mathrm{v} / \mathrm{v}$ ethanol. Entire tapeworms were stained with Langeron's alcoholic chlorhydric carmine (Langeron, 1949), differentiated in acid ethanol, dehydrated through a gradual ethanol series, cleared in beechwood creosote and mounted in Canada balsam. Thick transverse hand-cutting serial sections of proglottides were stained following the same procedure. Eggs were mounted in distilled water, after fixation for drawing. Three specimens were prepared for SEM as follows: post-fixed in $1 \%$ osmium tetroxide, dried with tetrametylsilane (Analyticals', Carlo Erba), mounted on stubs with adhesive tape, sputter coated with gold in a Thermo VG Scientific Polaron SC 7630 and examined with a Philips XL 30 scanning electron microscope. Microthrix density values (D) were obtained by counting microtriches from randomly selected areas of $1 \mu^{2}$. Voucher specimens of M. magna from Argentina were deposited at Colección Parasitológica del Museo Argentino de Ciencias Naturales "Bernardino Rivadavia", Buenos Aires, Argentina (MACN-Pa), and at the Natural History Museum, Geneva, Switzerland (MHNG). Syntypes of M. magna (Rego, dos Santos \& Silva, 1974) and M. loyolai (Pavanelli \& Machado dos Santos, 1992) from Helminthological Collection of the Instituto Oswaldo Cruz (CHIOC) were also studied. The information on taxonomic classification of fishes was obtained from FishBase Online (www.fishbase.org). All measurements are given in micrometers, unless otherwise stated, with the range followed by the mean, the standard deviation and the number of measurements (n) in parentheses. Measurements of microtriches were determined from photomicrographs. Illustrations were made with the aid of a camera lucida using Nomarski interference contrast in a Zeiss Axioscope microscope.

\section{RESULTS}

Monticellia magna (Rego, dos Santos \& Silva, 1974)

Nomimoscolex magna Rego, dos Santos \& Silva, 1974

Monticellia loyolai Pavanelli \& Machado dos Santos, 1992

Figs 1-14

Type host: Pimelodus clarias (Bloch, 1782) (junior synonym) (= P. blochii Valenciennes, 1840 , original combination). 

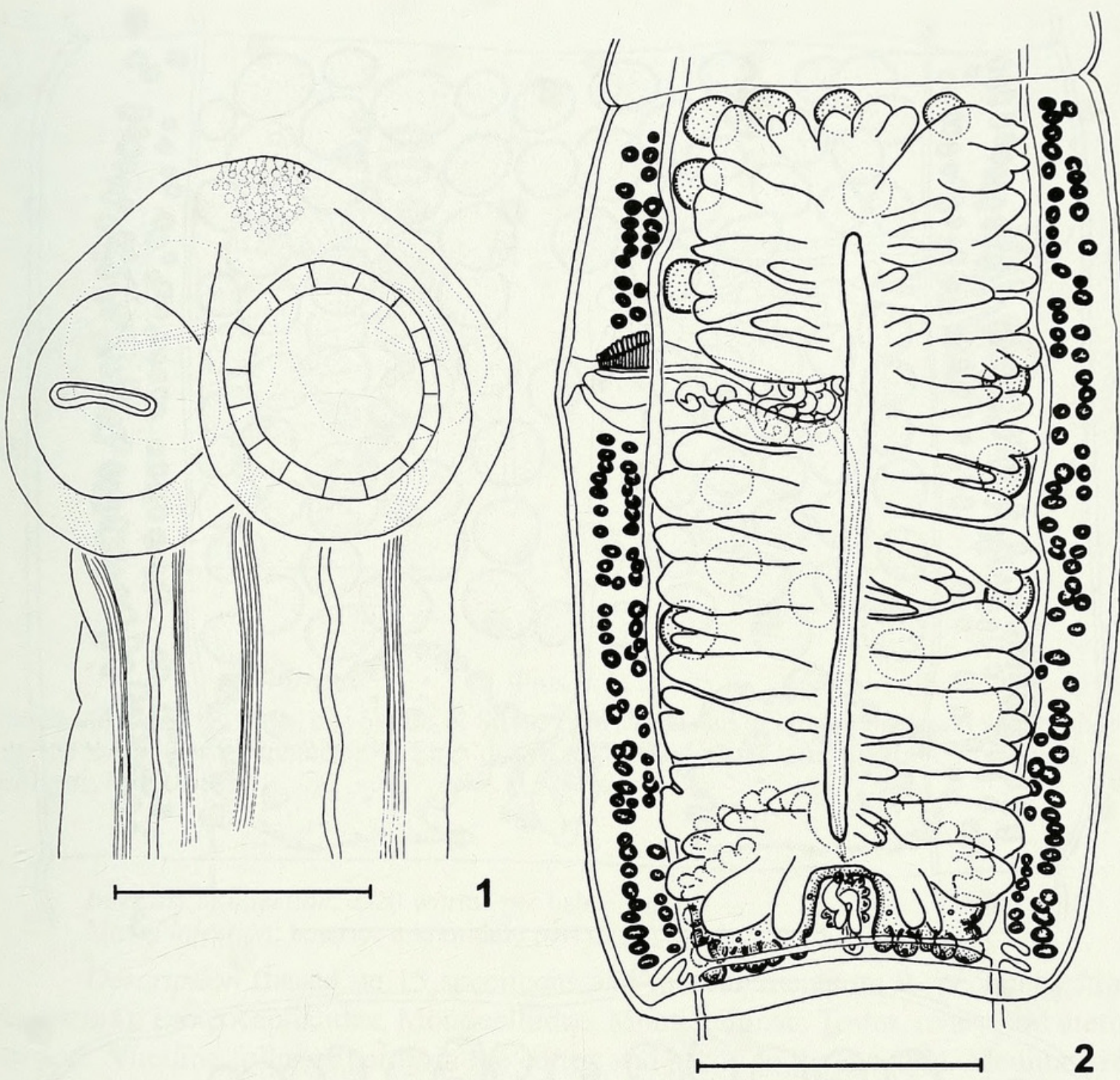

FIGS 1-2

Monticellia magna (Rego, dos Santos \& Silva, 1974). 1. Scolex, apical region showing unicellular gland cells. 2. Gravid proglottis, ventral view. Scale-bars: $1=250 \mu \mathrm{m} ; 2=500 \mu \mathrm{m}$.

Additional hosts: Pimelodus albicans (Valenciennes, 1840), vernacular name: moncholo, bagre blanco; Pimelodus argenteus Perugia, 1891, vernacular name: bagre blanco; Pimelodus maculatus Lacépède, 1803, vernacular name: bagre amarillo (Siluriformes: Pimelodidae).

Material studied: Argentina: 1) Buenos Aires Province, Buenos Aires Port, La Plata riv-

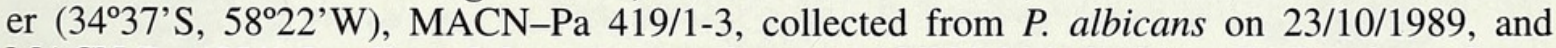
MACN-Pa 423/1-2 collected from P. maculatus on 10/09/1994. 2) Santa Fé Province, Santo Tomé City, Colastiné river (tributary of Paraná river) ( $\left.31^{\circ} 40^{\prime} \mathrm{S}, 60^{\circ} 46^{\prime} \mathrm{W}\right)$, MACN-Pa 423/3-4 and MNHG 34660 INVE, collected from $P$. maculatus on 15/02/2002 and 31/07/2001 respectively, and MACN-Pa 424/1-2 and MNHG 34661 INVE collected from P. argenteus on 13/12/2002. Type specimens from Brazil: 1) Mato Grosso State, Esperanza Port, syntypes $M$. magna (Rego, dos Santos \& Silva, 1974) CHIOC 31049 a-c, 2 contracted specimens; CHIOC 33137 (= 4476), fragment of strobila; CHIOC 33139 (= 4480), fragment of strobila. 2) Paraná State, Paraná river, M. loyolai (Pavanelli \& Machado dos Santos, 1992), CHIOC 32715 (holotype); CHIOC $32716 \mathrm{c}-\mathrm{d}$ and $32717 \mathrm{a}-\mathrm{b}$ transverse sections of proglottides (paratypes).

Prevalence: $40 \%$ (80 P. albicans examined), 33\% (6 P. argenteus examined), 70\% (212 P. maculatus examined). 

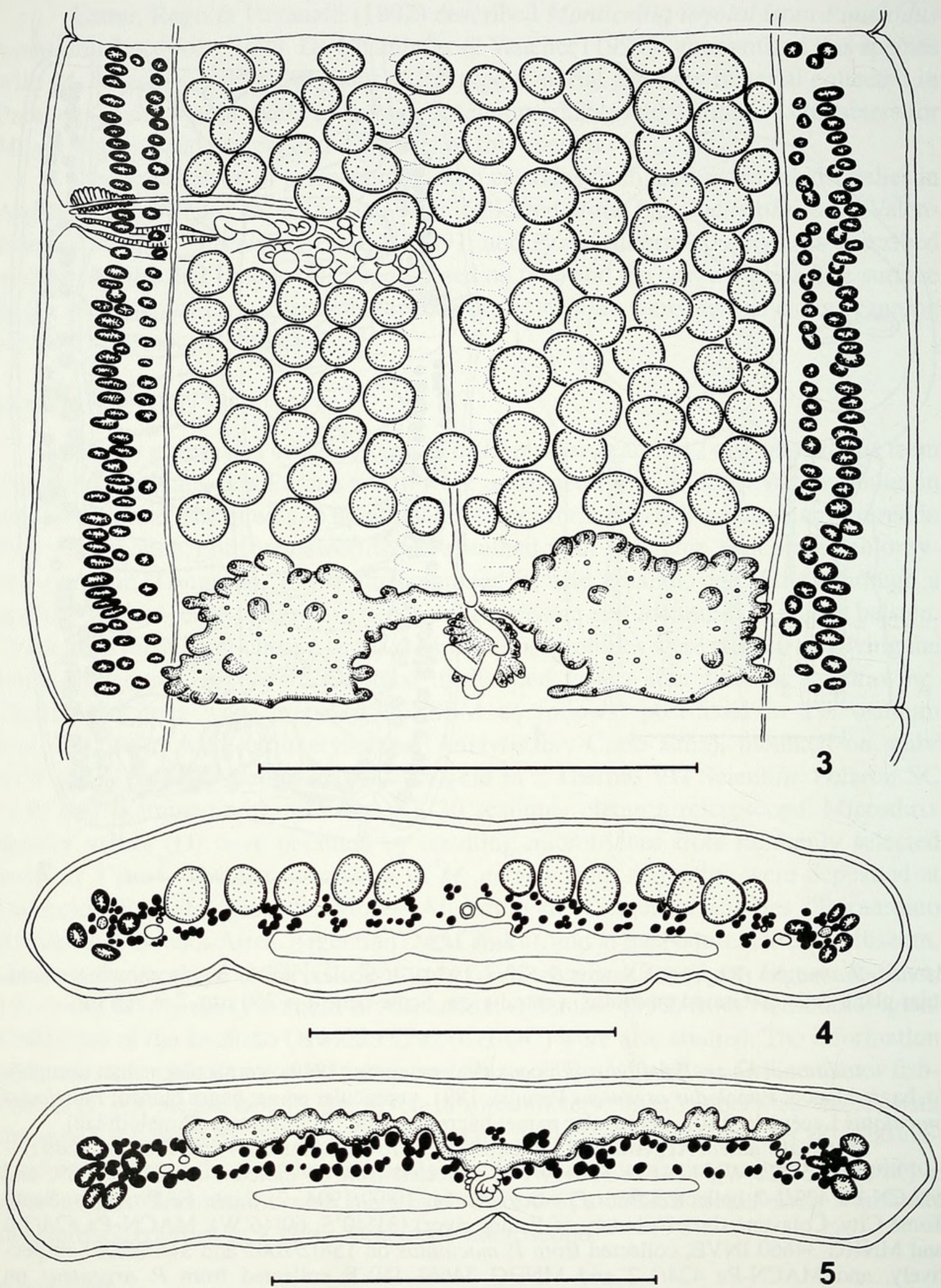

FIGS 3-5

Monticellia magna (Rego, dos Santos \& Silva, 1974). 3. Mature proglottis, dorsal view. 4-5. Transverse sections of proglottides showing internal longitudinal musculature, and topography of the genitalia. 4. Transverse section anterior to ovary. 5. Transverse section at level of ovary. Scale-bars: $3-5=500 \mu \mathrm{m}$. 


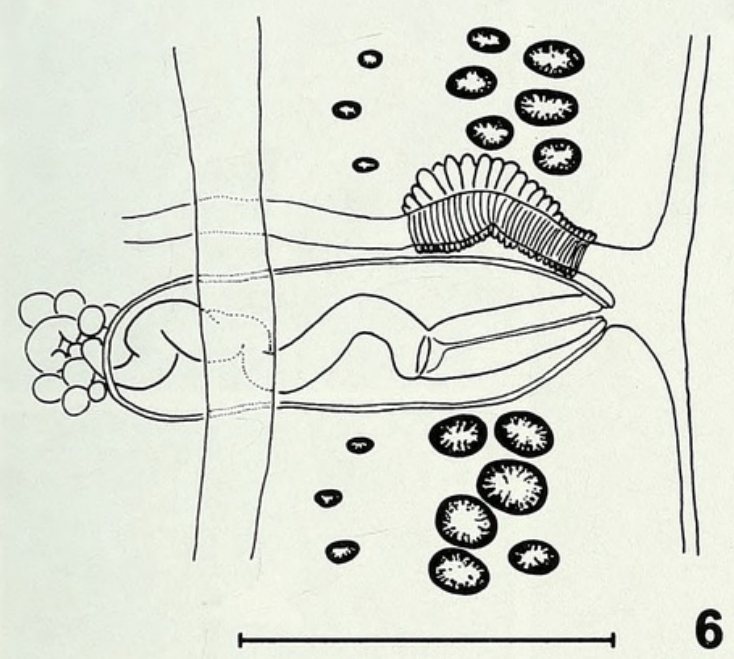

6

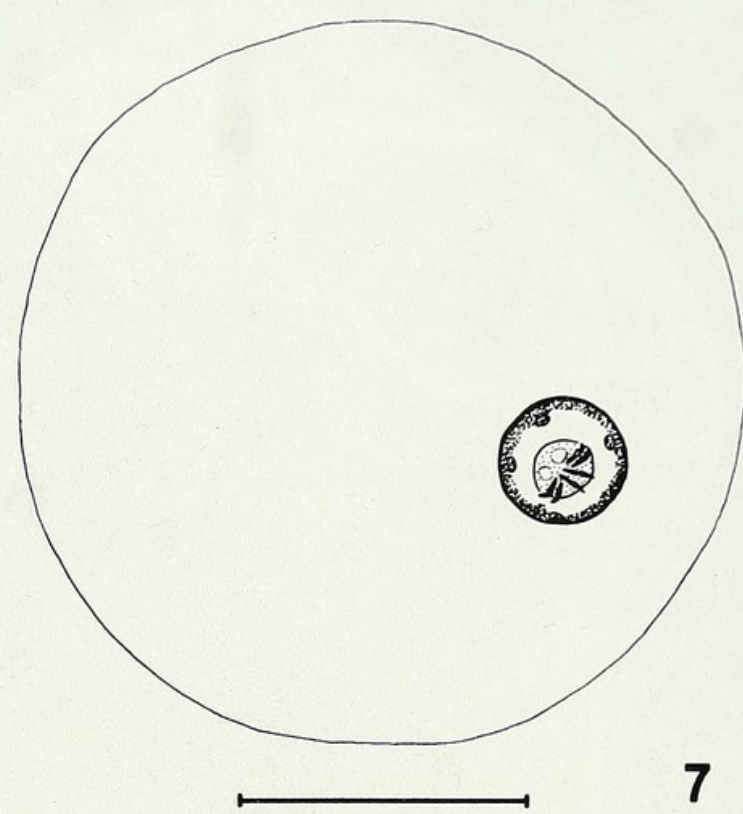

FIGS 6-7

Monticellia magna (Rego, dos Santos \& Silva, 1974). 6. Detail of cirrus pouch and vagina showing the asymmetrical sphincter. 7. Eggs drawn in distilled water, after fixation. Scale-bars: $6=$ $200 \mu \mathrm{m} ; 7=100 \mu \mathrm{m}$.

Intensity of infection: 2-20 worms per fish.

Site of infection: anterior and middle part of intestine.

Description (based on 15 specimens and measurements on 9 specimens from Argentina): Proteocephalidea, Monticelliidae, Monticelliinae. Testes, ovary and uterus cortical. Vitelline follicles partly in the cortex and partly in the medulla. Medium size worms, 23-125 mm, flattened dorsoventrally. Strobila acraspedote, anapolytic, consisting of 53-125 $(\mathrm{n}=9)$ proglottides: 20-60 immature, 8-22 mature, and 12-60 gravid.

Scolex wider than proliferation zone (Figs 1, 8), 480-830 (582 $\pm 58, n=9)$ wide. Apical organ absent, numerous spherical-shaped glandular cells with granular inclusions, distributed in apical region. Apical region of scolex proper covered with densely packed filiform microtriches 1.1-1.3 $(n=4)$ long, 0.1 wide, $D=21-25(n=4)($ Fig. 9). Suckers spherical to oval, unilobate, uniloculate, strongly muscular, 220-300 (246, n = 18) long, 160-300 (217) wide. Central cavity surface of suckers covered with filiform microtriches 0.8-1.2 $(\mathrm{n}=5)$ long, 0.1 wide, interspersed with spiniform microtriches 0.9-1.1 $(\mathrm{n}=6)$ long, $0.2-0.3$ wide, $\mathrm{D}=23$ filiform : 1-2 spiniform $(\mathrm{n}=4)$ (Fig. 11). Marginal ring surface of suckers covered with filiform microtriches 0.9-1.2 $(n=5)$ long, 0.1 wide, interspersed with spiniform microtriches 1.0-1.3 $(n=6)$ long, 0.2-0.3 wide, $D=14-20$ filiform : 1-2 spiniform $(n=4)$ (Fig. 10). Nonadherent surface of suckers covered with filiform 1.0-1.2 $(\mathrm{n}=5)$ long, 0.1 wide, interspersed with spiniform microtriches, 1.1-1.3 $(\mathrm{n}=4)$ long, 0.2 wide, $\mathrm{D}=8$-14 filiform : 2-3 spiniform $(\mathrm{n}=4)$ (Fig. 12). Proliferation zone (neck), 800-3000 (1422, $\mathrm{n}=9)$ long, surface covered with spiniform microtriches, 0.6-0.8 $(n=4)$ long, 0.2 wide, $D=31-35(n=4)$ (Fig. 13). 

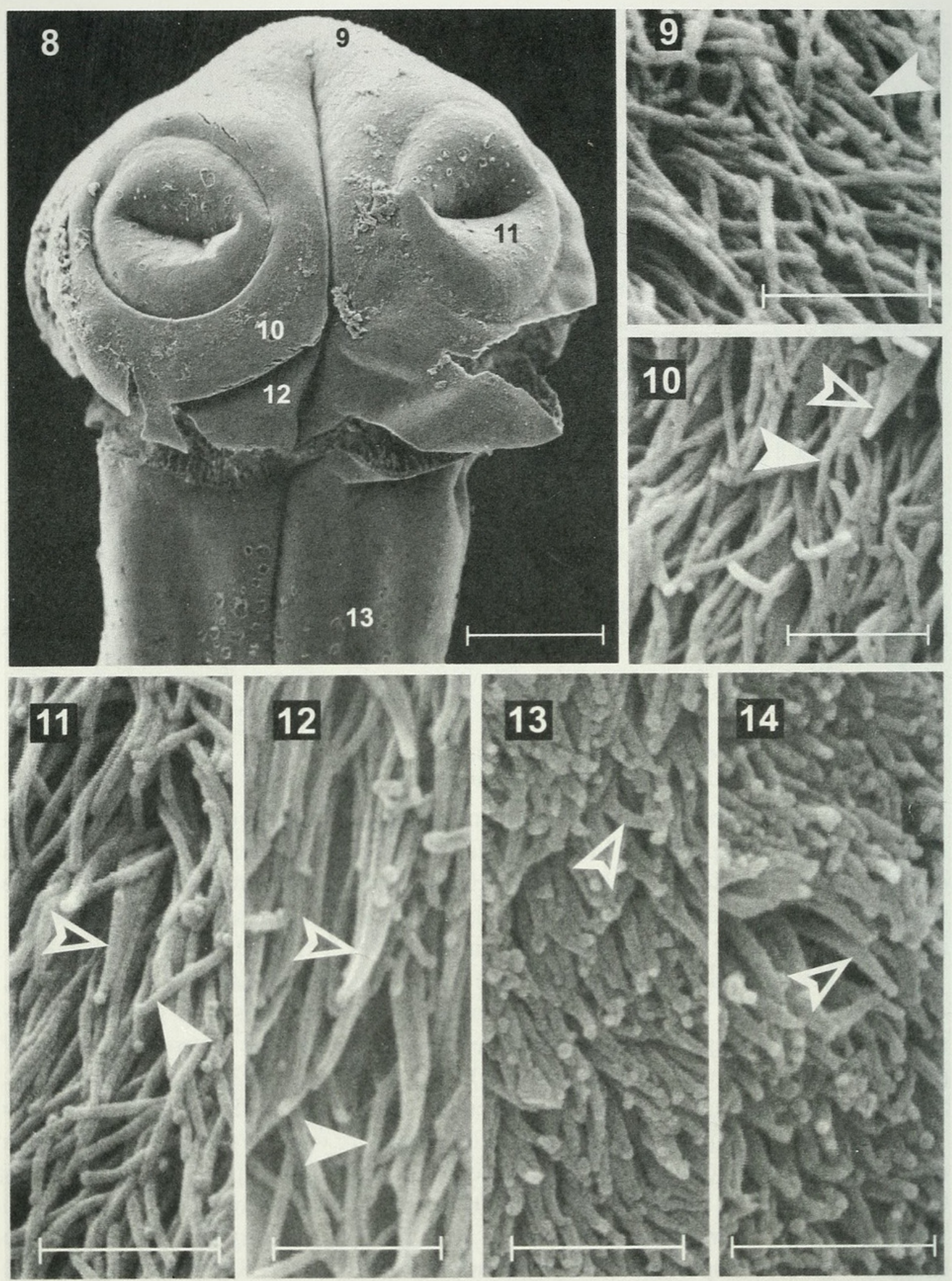

FIGS 8-14. Monticellia magna (Rego, dos Santos \& Silva, 1974) SEM micrographs. 8. Scolex in dorsoventral view, and positions of high magnification views for Figs 9-13. 9. Apical region surface, filiform microtriches. 10-12. Suckers: marginal ring, central cavity, and nonadherent surface, respectively, filiform microtriches interspersed with spiniform microtriches. 13. Proliferation zone surface, spiniform microtriches. 14. Immature proglottis surface, spiniform microtriches. Scale-bars: $8=100 \mu \mathrm{m} ; 9-12,14=1 \mu \mathrm{m} ; 13=2 \mu \mathrm{m}$. Full arrows show filiform microtriches, empty arrows show spiniform microtriches. 
Immature proglottides wider than long, 120-590 (338, $\mathrm{n}=12)$ long, 430-800 (598) wide. Immature proglottides surface covered with spiniform microtriches 0.6-0.7 $(n=5)$ long, 0.2 wide, $D=38-43(n=4)$ (Fig. 14). The surface of proliferation zone and the immature proglottis is covered with spiniform microtriches, and they are the regions with higher densities ( $\mathrm{D}=31-35$ and 38-43 respectively). Mature proglottides wider than long or longer than wide, 400-1010 (674 $\pm 154, \mathrm{n}=37)$ long, 880-2620 $(1340 \pm 547)$ wide (Fig. 3). Gravid proglottides wider than long or longer than wide, 500-2200 (1150 $\pm 373, \mathrm{n}=34)$ long, 870-2740 (1602 \pm 621$)$ wide (Fig. 2).

Internal longitudinal musculature strongly developed, forming thick fibre bundles, delimiting a reduced medulla. Osmoregulatory canals situated between testes and vittelline follicles. Ventral canal, 12-20 in diameter, with secondary osmoregulatory canals ending on ventral surface lateral to ovarian lobes. Dorsal canal, 5-10 in diameter (Figs 4, 5).

Testes cortical, total number 85-146 $(106, \mathrm{n}=22)$ in mature proglottides, 40$100(70, \mathrm{n}=18)$ in diameter; in one layer, in two fields connected anteriorly and posteriorly (Fig. 3). Occasionally, 1-3 testes overlapping vas deferens and distal part of cirrus pouch. Cirrus pouch pyriform with thin muscular wall, 210-320 (260 $\pm 36, n=$ 31) long, 40-85 (66 \pm 13$)$ wide; occupying $21-29 \%(24 \% \pm 2, n=31)$ of proglottis width in mature proglottides. Cirrus occupying about $30-62 \%$ of cirrus pouch length. Vas deferens coiled, 20-25 in diameter, usually not surpassing mid-line of body in mature proglottides. Genital pores irregularly alternating, situated anteriorly at $20-42 \%$ $(28 \% \pm 4, \mathrm{n}=31)$ of proglottis width.

Vagina anterior (99\%) to cirrus pouch, 13-20 in diameter, strongly asymmetrical and muscular sphincter present (Fig. 6). Ovary cortical, with 2 lobulate lobes; occupying $56-74 \%(67 \% \pm 4, \mathrm{n}=31)$ of proglottis width in mature proglottides.

Vitelline follicles cortical and paramuscular, with 1-2 follicles lying in medulla. Forming 2 lateral bands concentrated in mid-lateral region of proglottis, interrupted at cirrus pouch and vagina level on ventral side, reaching $98-100 \%$ of total proglottis length (Figs 3, 4, 5).

Uterine primordium stem and uterine branches cortical. Uterine branches occupying up to $70 \%$ of gravid proglottis width; $19-29(22, \mathrm{n}=14)$ lateral branches opposite to cirrus pouch side, and 18-28 (20) on cirrus pouch side. Cortical uterine diverticula nearly completely overlap the ovary. Mature eggs released by a ventral longitudinal slit (Fig. 2). Eggs with thick hyaline outer envelope, 160-275 (228, n = 7) in diameter; embryophore , 35-48 $(41, n=7)$ in diameter; oncosphere $18-20(n=7)$ in diameter; hooks 10-12 long (Fig. 7).

\section{DISCUSSION}

The genus Monticellia La Rue, 1911 includes 11 species, all distributed in the Neotropical region: M. amazonica de Chambrier \& Vaucher, 1997, M. belavistensis Pavanelli, Machado, Takemoto \& dos Santos, 1994, M. coryphicephala (Monticelli, 1891), M. dlouhyi de Chambrier \& Vaucher, 1999, M. lenha Woodland, 1933, M. magna, M. mandi (Pavanelli \& Takemoto, 1996), M. megacephala Woodland, 1934, M. ophisterni Scholz, de Chambrier \& Salgado-Maldonado, 2001, M. spinulifera, Woodland, 1935, and M. ventrei de Chambrier \& Vaucher, 1999. M. diesingii 
(Monticelli, 1891) and M. macrocotylea (Monticelli, 1892) are considered species inquirendae (Rego et al., 1999).

Among the morpho-anatomical features studied in this redescription the following combination of characters are important to characterise $M$. magna: (1) vagina anterior to cirrus pouch; (2) muscular asymmetrical sphincter present; (3) testes in one layer and in two fields connected anteriorly and posteriorly; (4) vitelline follicles distributed cortical, paramuscular and a few follicles medullary; (5) internal longitudinal musculature strongly developed; and (6) scolex with filiform microtriches in apical region, filiform and spiniform microtriches in central cavity, marginal ring and nonadherent surface of suckers, and spiniform microtriches in proliferation zone and immature proglottides.

The syntypes of $M$. magna were studied and the conspecificity with the specimens from Argentina was confirmed. Transverse sections were not available from the material examined. The holotype and the paratypes of Monticellia loyolai $(=M$. magna) were also studied. The asymmetrical vaginal sphincter and uterine branches nearly completely overlapping the ovary were clearly observed in type specimens. The vitelline follicles are situated cortical, paramuscular, and medullary (Figs 15, 16). The same topography was observed in the specimens collected from $P$. albicans, $P$. argenteus and $P$. maculatus from Argentina, thus the conspecificity with $M$. magna was also confirmed.

In the genus Monticellia, only $M$. spinulifera has been partially examined with SEM (Rego, 1999). Even when this author studied the sucker at very low magnification, and the giant spiniform microtriches on the marginal ring of the sucker could be easily observed. However, from the photomicrograph it is not known if the spiniform microtriches are the only kind of microtriches on the marginal ring surface or if they are interspersed with other types of microtriches. Therefore, it is necessary to study in detail all the regions of the scolex proper to confirm the microthrix distribution of M. spinulifera. To date, in the Neotropical proteocephalids only Nomimoscolex semenasae Gil de Pertierra, 2002 (Monticelliidae, Zygobothriinae), and M. magna in this paper were completely analysed for the microthrix distribution with SEM.

Host-specificity varies widely among different taxa of fish helminths. Highly host-specific parasites are restricted to one host species and specificity declines as the number of suitable host species increases (Poulin, 1998). The South American proteocephalideans have been considered to be specific to one fish host species. In fact, a few examples of species having more than one final host were registered: (1) Amazotaenia yvettae de Chambrier, 2001 from Brachyplatystoma filamentosum Lichtenstein, 1819, and B. vaillantii Valenciennes, 1840; (2) Choanoscolex abscissus (Riggenbach, 1896) from Zungaro zungaro (Humboldt, 1821) [(= Paulicea luetkeni (Steindachner, 1876)], Pseudoplatystoma corruscans (Agassiz, 1829), P. fasciatum Linnaeus, 1766, and Raphiodon vulpinus Spix \& Agassiz, 1829 (see Rego et al., 1999); (3) Harriscolex kaparari (Woodland, 1934) from P. corruscans, and P. tigrinum (Valenciennes, 1840); (4) Monticellia magna from Pimelodus albicans (new record), P. argenteus (new record), P. clarias, and P. maculatus; (5) M. ventrei de Chambrier \& Vaucher, 1999 from Luciopimelodus pati (Valenciennes, 1836) (new record), and Pinirampus pirinampu (Spix \& Agassiz, 1829); (6) Nomimoscolex microacetabula Gil de Pertierra, 1995 from 

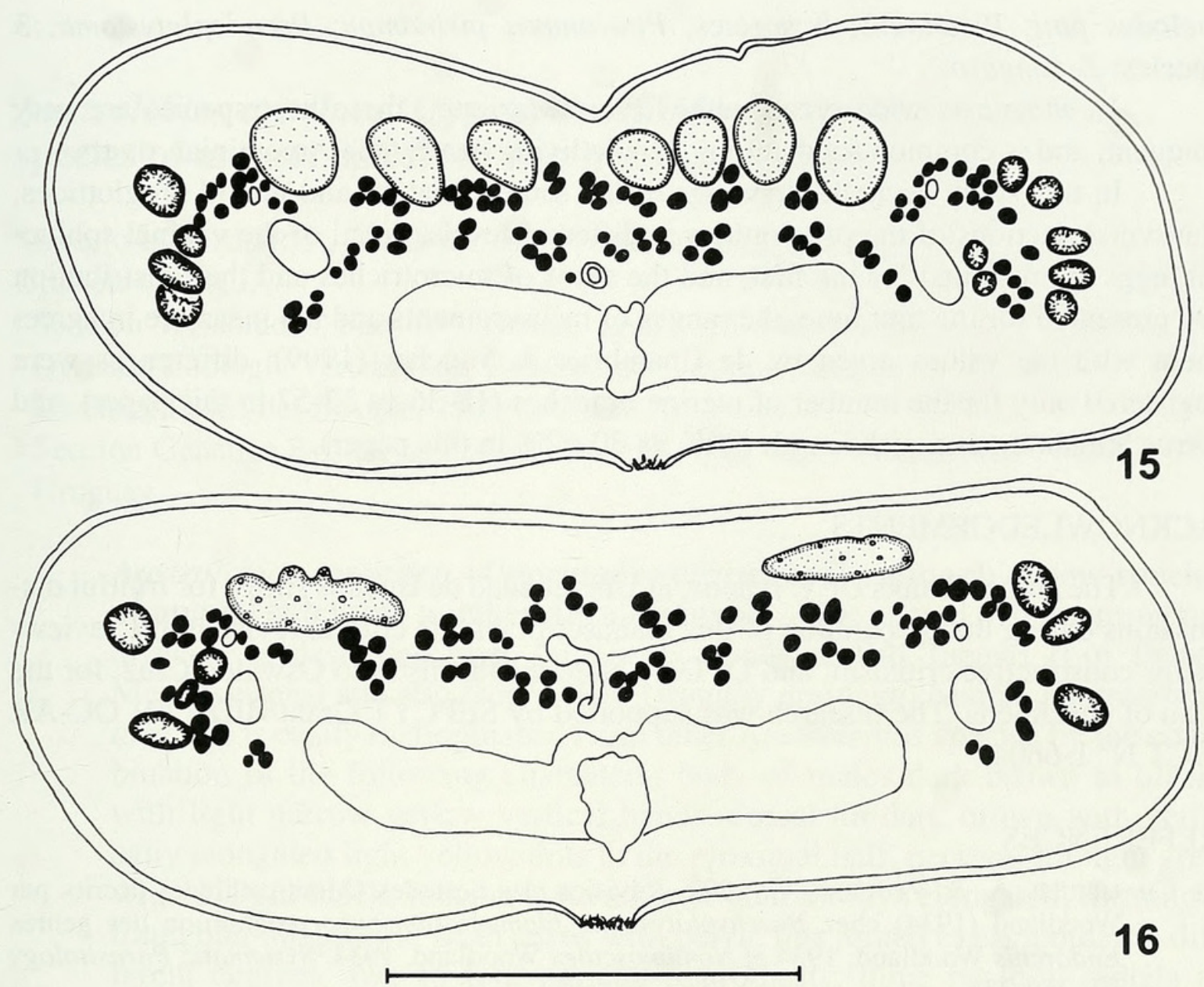

FIGS 15-16

Monticellia magna (Rego, dos Santos \& Silva, 1974), transverse sections of proglottides drawn from holotype CHIOC $32715 \mathrm{a}$, showing internal longitudinal musculature, and topography of the genitalia. 15. Transverse section anterior to ovary. 16. Transverse section at level of ovary. Scale-bar: $15,16=500 \mu \mathrm{m}$.

P. albicans, and P. maculatus; (7) N. suspectus Zehnder, de Chambrier, Vaucher \& Mariaux, 2000 from B. filamentosum, B. vaillantii, and Z. zungaro $[(=$ B. flavicans (Castelnau, 1885)]; (8) Nupelia tomasi de Chambrier \& Vaucher, 1999 from Trachelyopterus galeatus (=Parauchenipterus galeatus) (Linnaeus, 1766), and $T$. cff. striatulus (= P. striatulus) (Steindachner, 1877); (9) Peltidocotyle rugosa Diesing, 1850 (see Zehnder \& de Chambrier, 2000) from P. corruscans, P. fasciatum, and $P$. tigrinum; (10) Peltidocotyle lenha (Woodland, 1933) (see Zehnder \& de Chambrier, 2000) from Z. Zungaro, and Sorubimichthys planiceps (Spix \& Agassiz, 1829); and (11) Proteocephalus microscopicus Woodland, 1935 from Cichla monoculus Spix \& Agassiz, 1831, and Cichla ocellaris Bloch \& Schneider, 1801.

Poulin $(1992,1997)$ stated that high host-specificity can be an artefact of inadequate sampling, and among species of parasites of freshwater fishes sampling effort explains much of the variability in host-specificity. The number of South American proteocephalid species known parasitising more than one fish host might be correlated with a larger sampling effort. Among the fishes mentioned previously $81 \%$ are commercially exploited (Cichla, 2 species; Brachyplatystoma, 2 species; Luciopi- 
melodus pati; Pimelodus, 3 species; Pinirampus pirinampu; Pseudoplatystoma, 3 species; Z. zungaro)

M. magna is widespread within Pimelodus spp., these host species are very frequent, and is common food among people living nearby the Argentinian rivers.

In this study accurate drawings of the scolex, mature and gravid proglottides, transverse sections of the proglottides at different levels, detail of the vaginal sphincter, eggs are revisited for the first, and the types of microtriches and their distribution are presented for the first time, the ranges of measurements and the mean are in agreement with the values given by de Chambrier \& Vaucher (1999), differences were registered only for the number of uterine branches (18-36 vs 37-57 in this paper), and cirrus length/cirrus pouch length (30\% vs $30-62 \%$ in this paper).

\section{ACKNOWLEDGEMENTS}

The author thanks Dr V. Ivanov, at Universidad de Buenos Aires, for fruitful discussions during the preparation of this manuscript and its critical revision; the reviewer for constructive critisism; and Dr Dely Noronha, at Instituto Oswaldo Cruz, for the loan of specimens. The research was supported by SEPCYT Grant BID 1201 OC-AR PICT No $1-6604$.

\section{REFERENCES}

DE Chambrier, A. \& Vaucher, C. 1997. Révision des cestodes (Monticelliidae) décrits par Woodland (1934) chez Brachyplatystoma filamentosum avec redéfinition des genres Endorchis Woodland, 1934 et Nomimoscolex Woodland, 1934. Systematic Parasitology 37: 219-233.

De Chambrier, A. \& Vaucher, C. 1999. Proteocephalidae and Monticelliidae (Eucestoda: Proteocephalidea) parasites de poissons d'eau douce au Paraguay, avec descriptions d'un genre nouveau et de dix espèces nouvelles. Revue suisse de Zoologie 106: 165-240.

Langeron, M. 1949. Précis de Microscopie. $7^{\text {th }}$ ed. Paris: Masson \& Cie, 1429 pp.

REGO, A. A. 1999. Scolex morphology of proteocephalid cestodes parasites of Neotropical freshwater fishes. Memórias do Instituto Oswaldo Cruz 94: 37-52.

Rego, A. A., Chubb, J. C. \& Pavanelli, G. C. 1999. Cestodes in South American freshwater teleost fishes: keys to genera and brief description of species. Revista Brasileira de Zoologia 16: 299-367.

Pavanelli, G. C. \& Machado dos Santos, M. H. 1992. Goezeella agostinhoi sp. n. e Monticellia loyolai sp. n., cestóides proteocefalídeos parasitas de peixes pimelodídeos do río Paraná, Paraná, Brasil. Revista Brasileira de Parasitologia Veterinaria 1: 45-50.

Poulin, R. 1992. Determinants of host-specificity in parasites of freshwater fishes. International Journal for Parasitology 22: 753-758.

Poulin, R. 1997. Parasite faunas of freshwater fish: the relationship between richness and the specificity of parasites. International Journal for Parasitology 27: 1091-1098.

Poulin, R. 1998. Evolutionary ecology of parasites: from individuals to communities. Chapman \& Hall, 212 pp. 


\section{$2 \mathrm{BHL}$ Biodiversity Heritage Library}

Gil de Pertierra, Alicia Alida. 2004. "Redescription of Monticellia magna (Rego, dos Santos \& Silva, 1974) (Eucestoda: Monticelliidae) parasite of Pimelodus spp. (Pisces: Siluriformes) from Argentina, and morphological study of microtriches." Revue suisse de zoologie 111, 11-20.

https://doi.org/10.5962/bhl.part.80222.

View This Item Online: https://www.biodiversitylibrary.org/item/128357

DOI: https://doi.org/10.5962/bhl.part.80222

Permalink: https://www.biodiversitylibrary.org/partpdf/80222

\section{Holding Institution}

Smithsonian Libraries

\section{Sponsored by}

Biodiversity Heritage Library

\section{Copyright \& Reuse}

Copyright Status: In Copyright. Digitized with the permission of the rights holder

Rights Holder: Muséum d'histoire naturelle - Ville de Genève

License: http://creativecommons.org/licenses/by-nc-sa/3.0/

Rights: https://www.biodiversitylibrary.org/permissions/

This document was created from content at the Biodiversity Heritage Library, the world's largest open access digital library for biodiversity literature and archives. Visit BHL at https://www.biodiversitylibrary.org. 